\title{
Breaking the Mirror: Alain Badiou's Reading of Jacques Lacan
}

\begin{abstract}
"The philosopher is inscribed (in the sense that one speaks of a circumference of a circle) in the discourse of the master. He plays the role of the fool there. That does not mean that what he says is foolish; it is even more than useful. Read Shakespeare. [...] The court fool has a role: the one of being the place-holder for truth." Jacques Lacan, “L'Étourdit” (1972)
\end{abstract}

In the late 1960s, Louis Althusser asked the young Alain Badiou to report on Jacques Lacan's seminars and he invited him to give a lecture on Lacan in the framework of his seminar at the École Normale Supérieure. This assignment was the origin of Badiou's rich and fruitful confrontation with psychoanalytical concepts, which can be traced throughout his whole philosophical career. Badiou has striven, in multiple books, to come to terms with the inheritance of Lacan: his early 1982 book Theory of the Subject was heavily indebted to Lacan's formalism, and the first two volumes of Being and Event (published in 1988 and in 2006) included a chapter on Lacan. In addition, Badiou published a series of texts on Lacan in Conditions (1992), and in 1994 he wrote a brief essay on Lacan's L'Étourdit and dedicated an entire seminar to Lacan's relation to philosophy. In the following article, I will attempt to elucidate Badiou's idiosyncratic interpretation of Lacan as well as his conceptual points of divergence with the psychoanalyst, which touch upon the relationship between philosophy and antiphilosophy, the different localization of the void in relation to the subject and the notion of eternal and universal truths.

Jacques Lacan, “LÉtourdit” in: Autres Écrits, Seuil, Paris, 2001, p. 453. I am quoting here the unpublished translation by R. Klein, http://www.lacanianworks.net/?p=221, accessed 25 July 2021.

* Columbia University, USA 


\section{What is (anti)philosophy?}

Alain Badiou's interest in Lacan has always been grounded in philosophy rather than in psychoanalysis. In most of his comments on Lacan, Badiou does not propose a synchronic perspective of Lacan's conceptual system, he rather focuses on specific and concrete points of intersection between psychoanalysis and philosophy. Badiou portrays Lacan as an antiphilosopher. The term "antiphilosophy" began to appear in Badiou's writings in 1988 along with the publication of the first volume of Being and Event. In fact, the progressive definition of antiphilosophy was parallel with Badiou's perception of himself as a philosopher. Although his early books such as Theory of the Subject were rooted in philosophical discourse and relied on mathematical formalizations, it was only with the publication of Being and Event in 1988 that Badiou began to see his task as renewing the philosophical tradition. He came to be convinced that philosophy could not survive in the future unless it confronted Lacanian psychoanalysis.

So what exactly does the term "antiphilosophy" mean for Badiou? Antiphilosophy constitutes a tension internal to philosophical discourse. Like sophistry, antiphilosophy negates the category of truth. Antiphilosophers include figures such as Blaise Pascal, Friedrich Nietzsche, Ludwig Wittgenstein, and Jacques Lacan. Thus, Lacan, one of the antiphilosophers, would criticize philosophy for being a master discourse and reject philosophy's ambition to posit itself as a theory of the real. For Badiou, the antiphilosopher is someone who challenges philosophy from the side of the ungraspable real that the philosophical schematism is unable to comprehend. He claims that philosophy is too distant from the real and that philosophy's belief that "the One exists" forecloses the real. In antiphilosophical discourse, the inconsistency of the real disseminates and corrodes philosophy. For these reasons, antiphilosophers do not strive to produce a philosophical system as such, rather they seek a mode of expression that would be able to catch the real.

In general, antiphilosophical thought embraces fragmentary forms; it works as an apparatus whose goal is to demonstrate what cannot be said - Lacan's notion of the matheme might serve as a perfect example of such an apparatus. For Lacan sees the matheme as the only possible way to capture the real; it is the only form of transmissible knowledge of the real. However, in the Lacanian discourse, the matheme does not represent a rigorous mathematical formaliza- 
tion, it resembles a one-way road of mathematics. Matheme is mathematics ad absurdum, mathematics that touches the limits of its own discourse. The failure of mathematics is what in the matheme exposes the real.

In Badiou's writings from the period of Being and Event, the signification of antiphilosophy remains ambiguous: in some cases, the word "antiphilosopher" refers to the figure of the sophist, in others, the antiphilosopher is described as someone who challenges the Master discourse of philosophy. Tzuchien Tho remarked that it is important to distinguish the antiphilosopher from the sophist, because "both the antiphilosopher and the sophist reject the access of the subject to truth, but the antiphilosopher provides a certain kind of 'cure' to the philosopher's pretentions, an act that orients the subject towards the real." ${ }^{2}$ Unlike the sophist, the antiphilosopher makes philosophy undergo the 'cure' of the real. Thus, the antiphilosopher does not completely reject the field of philosophy, rather he challenges it from within. While the sophist negates the existence of truths by claiming, in accordance with democratic materialism, that "there are only bodies and languages" 3 and that no event is possible in a given reality, the antiphilosopher indexes the existence of the real, which exceeds bodies and languages. Thus, we might say that the sophist challenges philosophy from the side of the imaginary reality, ${ }^{4}$ while the antiphilosopher challenges the philosopher from the side of the real. The sophist's reduction of all essences to bodies and languages might resemble the regime of the postmodern production of simulacra and the proliferation of the imaginary without any symbolic point d'arrêt. In contrast, the antiphilosopher highlights the excess of the philosopher's symbolization, the real that cannot be symbolized.

To put it differently, if the activity of the sophist relates to non-sense (non-sens), that of the antiphilosopher relates to $a b$-sense ( $a b$-sens). Antiphilosophy is $a b$-philosophy; it is the return of the extra-philosophical leftover (excès) into the philosophical discourse as such. In There's No Such Thing as a Sexual Rela-

Tzuchien Tho, “Antiphilosophy”, in Steven Corcoran (ed.), The Badiou Dictionary, Edinburgh, The Edinburgh University Press, 2015, p. 13.

3 Alain Badiou, Logics of Worlds: Being and Event, 2, trans. A. Toscano, New York, Continuum, 2009, p. 1.

4 For Lacan, the category of "reality" pertains to the imaginary and we could argue that the sophist who rejects the notion of truth and the distinction between the real and the imaginary remains trapped by the imaginary. 
tionship: Two Lessons on Lacan, Badiou comments on Lacan's obscure 1973 text L'Étourdit and his interpretation of the real. Badiou remarks that in L'Étourdit, the real can be defined as the absence of sense: "the real may be defined as sense qua $a b$-sense. The real is ab-sense, hence absence of sense, which obviously implies that there is such a thing as a sense." ${ }^{5}$ According to Badiou, the real is the leftover of sense, but this also means that the real needs sense, otherwise there would be no real as such. This real, or $a b$-sense, is a void, an absence within sense and not its negation.

This implies that we must clearly distinguish between non-sense, which would be the true negation of sense, and $a b$-sense, the empty place within sense, a void that operates at the same level as sense. For this reason, Badiou emphasizes that Lacan's intention is not to declare the non-sense of the real. Lacan asserts "that an access to the real can be opened only if it is assumed that the real is like an absence in sense, an ab-sense, or a subtraction of, or from, sense. Everything hinges on the distinction between ab-sense and non-sense." $\mathrm{Ab}$-sense is not the pure negation of sense, it is rather the absence of a relation to sense that, in this case, also means the absence of a sexual relation or what Badiou calls with Lacan sense $a b$-sex. Ab-sense is a leftover, an excess, a void escaping the symbolization. $A b$-sense prevents sense from being conceived as a totality, as the One - there will always be something escaping sense. In fact, Lacan despises philosophy because he is convinced that philosophy reduces everything to sense and to the homogeneous totality of the One. In order to attain the real, knowledge must suture itself affirmatively to its absence, to the void. Philosophy, at least in Lacan's perspective, cannot access the real.

If we accept the hypothesis that philosophy deals primarily with sense, the antiphilosopher - for whom the real serves as the refutation of philosophy can be interpreted as a figure connected with $a b$-sense. Antiphilosopher is an $a b$-philosopher, he or she is a kind of an exogenous dialectical presence within philosophy and does not oppose the existence of philosophy as such. The soph-

5 Alain Badiou, Barbara Cassin, There's No Such Thing as a Sexual Relationship: Two Lessons on Lacan, trans. S. Spitzer and K. Reinhard, New York, Columbia University Press, 2017, p. 49.

6 Ibid., p. 50.

7 In one of his typical puns, Jacques Lacan mockingly called philosophy "(h)ontologie," combining the words "honte" (shame) and ontology. 
ist, on the contrary, deals primarily with non-sense and stands outside of philosophy. This distinction could be summarized in a simple table:

\begin{tabular}{|c|c|c|}
\hline philosophy & sophistry & $\begin{array}{c}\text { antiphilosophy (Lacan's } \\
\text { psychoanalysis) }\end{array}$ \\
\hline sense & non-sense & ab-sense \\
\hline
\end{tabular}

\section{Through the looking glass and what philosophy found there}

So how does Badiou define philosophy's relationship to psychoanalysis? In Conditions, Badiou states that "[p]hilosophy is always the breaking of a mirror. This mirror is the surface of language, onto which the sophist reduces all the things that philosophy treats in its act. If the philosopher sets his gaze solely on this surface, his double, the sophist, will emerge, and he may take himself to be one."» This statement might be a subtle play with Lacanian vocabulary for it seems to allude to Lacan's two identifications constitutive of the subject: the mirror stage (and the related formation of the imaginary), and the Oedipus complex (and the formation of the symbolic). In "The Mirror Stage as Formative of the $I$ Function as Revealed in the Psychoanalytic Experience", Lacan remarked that "the specular image seems to be the threshold of the visible world." When Badiou evokes the image of the broken mirror, he could be affirming that philosophy needs to go beyond the imaginary and deal with the symbolic, because philosophy as the love of truth is always related to the symbolic. And if philosophy loves truth, it also means that it loves weakness because castration sustains the emergence of the symbolic within the second identification of the Oedipus complex. Conversely, the gaze of the sophist can only slide on the surface of the mirror. Instead of breaking the mirror, the sophist remains confined to doxa. He is imprisoned within the imaginary and never crosses the threshold of the visible world because he rejects the possibility of any symbolic criteria that would enable it to see through and beyond this world. The universe of the sophist can be characterized by a proliferation of images; it is the world of the spectacle. Philosophy, on the other hand, is not spectacular - its goals are to break the mirror and index truths.

Alain Badiou, Conditions, trans. S. Corcoran, New York, Continuum, 2008, p. 25.

9 Jacques Lacan, Écrits, the First Complete Edition in English, trans. B. Fink, New York, W. W. Norton \& Company, 2006, p. 77. 
Lacan is convinced that philosophy is trapped within the Master's discourse due to its close connection with the second identification and the symbolic. According to him, philosophy falsely pretends that metalanguage exists. By positing the existence of the One, it is unable to grasp the real, $a b$-sense of the sexual (non)relationship. Yet, such conception of philosophy sharply contradicts Badiou's own philosophical project, for Badiou's goal is precisely to show that philosophy cannot be reduced to its internal temptation to postulate the existence of the One. Badiou endeavours to prove that there can be a philosophy for which the One would (in)exist and which would be able to capture the real. Philosophy, by responding critically to psychoanalytical objections, can affirm that the One exists only as the result of a constructive count, of the count-as-one. In other words, philosophy can be sutured to the immanent multiplicity of the real. So, when Badiou criticizes the sophist for reducing all the things to the surface of language and affirms that philosophy treats things in its act, he refers to his own philosophical project of stitching philosophy and the real.

For this reason, Badiou focuses primarily on Lacan's late 1970s writings, which include occasional references to set theory. In his seminar ...or Worse, given between 1971 and 1972, Lacan posited that the One does not exist. As Lacan puts it in the summary of this seminar, the One does not exist, there is one, or Y'a d'l'Un. Lacan claims: "as for the rest, I was fomenting no thought of the One, but on the basis of the fact of saying Y'a d'l'Un, I was going to the full terms that are demonstrated by its use, to make psychoanalysis thereof." ${ }^{10}$ In other words, he is convinced that the existence of the One is purely imaginary; the One occupies the place of semblance ${ }^{11}$ and the philosopher is someone who s'...oupire à l'Un.

But what exactly is the difference between saying that "the One exists" and that "there is one"? In ...or Worse, Lacan refers to the ZFC set theory, in which a set with only one element is still considered a set because no set can be an element of itself. In set theory, the One appears as a singleton, that means as a set that has an empty set as its only element: $\{\varnothing\}$. This leads Lacan to the deduction that "the One begins on the level at which there is one missing," ${ }^{12}$ that the One is

10 Jacques Lacan, ...or Worse, The Seminar of Jacques Lacan, Book XIX, trans. A. R. Price, Cambridge, Polity, 2018, p. 215.

${ }_{11} \quad$ Ibid., p. 126.

12 Ibid. 
precisely the set containing an empty set. The One is a set containing the void and it is by counting this void that we can affirm that the One (in)exists. Thus, the One has no positive existence as such; it emerges as an effect of the lack. The One is an effect of the act of counting. The formula "there is one" refers to this notion of the One.

According to Lacan, the existence of the One would lead to the foreclosure of the real. In L'Étourdit, he claims that philosophy lacks sens ab-sexe, that philosophy is ashamed of the real and tries to veil it by ( $h$ )ontologie. In addition, he alludes to the link between the existence of the One and the notion of individuality. Lacan emphasizes: “when I say Y'a d'l'Un, this doesn't mean that there is something of the individual. [...] That is to say, there is no other existence of the One but mathematical existence." ${ }^{13}$ Throughout his career, Lacan opposed North American ego psychology and the reduction of the subject to the ego. He interpreted the moralism of the superego in ego psychology and the effort to protect the ego from the instinctual id as an advanced form of alienation. Lacan saw ego psychology as a way to render Freud's teaching conformist and complacent to capitalism - such criticism might also have inspired Badiou's positive appraisal of the Lacanian legacy. In ego psychology, the notion of the subject-ego, of the individual, presupposes that the One exists. Yet, such a notion of the subject-One qua the individual would foreclose the inconsistency of the unconscious. For Lacan, the individual does not exist; the only thing that exists is the subject constituted by its immanent multiplicity of subsequent identifications.

If the One existed, how could we conceive the multiplicity and ephemerality of the phenomenal world? How would change be possible? The existence of the One might imply a conception of the world as a finite and closed totality, as l'Un-Tout. In contrast, if we posit that "there is one," we could see the world as a subtraction from being. We can imagine it as a more open, infinite system, a system that is pas-tout. These considerations might have inspired Badiou's discussion of the One in his seminar on Jacques Lacan. Badiou summarizes the difference between both statements as follows: while in the One exists, the One "subjugates the real at the very place of semblance," ${ }^{4}$ the sentence there is one,

13 Ibid., p. 165.

14 Alain Badiou, Lacan, Anti-philosophy 3, The Seminars of Alain Badiou, trans. K. Reinhard and S. Spitzer, New York, Columbia University Press, 2018, p. 55. 
"doesn't require thinking the One in terms of its being but [is] simply noting that there may be some One in a realm of operations that's important, as Lacan says, 'to turn into psychoanalysis'." ${ }^{15}$ On the ontological level, the One does not exist, it is a mere result of a count. However, if Lacan is convinced that philosophy thinks that the One exists, Badiou proves that there can be a philosophy for which there is one. The question of the One and its relation to the real is a crucial point that links Badiou's thinking to Lacan's investigations.

In Being and Event, Badiou clearly states that the One does not exist: "the One, which is not, solely exists as operation. In other words: there is no one, only the count-as-one." ${ }^{\prime 16}$ The inexistence of the One is the key aspect of Badiou's ontology; for Badiou there is only the count-as-one. Everything that is presented presents itself as a multiplicity; the One is a mere result of mathematical operations, it has no immanent existence as such. The structure is "what prescribes, for a presented multiple, the regime of its count-as-one." ${ }^{{ }^{17}}$ Being is composed of inconsistent and infinite multiplicities and ontology is the thought of these multiplicities qua multiplicities. But if these multiplicities are inconsistent, it also means that they cannot be described by language, for any language would count them as one and would abolish the inconsistent multiplicity.

For this reason, Badiou's ontological project relies heavily on mathematics. Mathematics, especially set theory, enables us to think multiplicities qua multiplicities and describe the actual infinite. This does not mean that being is composed of numbers; it means that mathematics is a discourse on being. Ontology qua mathematics is a way to describe being as such, to produce a transmissible knowledge of being. Yet, for this very reason, ontology no longer stands at the centre of philosophy; infinite multiplicities of being have something almost boring and banal about them. Badiou's understanding of being might remind us of Jacques Lacan's statement in l'Étourdit that "being by itself has no kind of sense." ${ }^{18}$ Thus, being constitutes philosophical $a b$-sense for Badiou, or to put it

15 Ibid., pp. 55-56.

16 Alain Badiou, Being and Event, trans. O. Feltham, New York, Continuum, 2008, p. 24.

17 Ibid., p. 24 .

18 Jacques Lacan, Autres Écrits, Paris, Seuil, 2001, 472. I am quoting here the unpublished translation by Richard Klein available at http://www.lacanianworks.net/?p=221, accessed 25 July 2021. 
differently, being is the philosopher's real. The task of philosophy necessarily exceeds ontology, for it consists in indexing and localizing truths.

Thus, there seems to be a clear continuity between Lacan's late embrace of set theory and Badiou's ontology. While Lacan's reductionist point of view circumscribes philosophy to the existence of the One, Badiou proves that there can indeed be philosophy without the One, that there can be a philosophy of Y'a d'l'Un. Badiou's philosophy does not foreclose the real. We might argue that being plays a similar structural role for Badiou as the real does for Lacan. This is not to say that it would be possible to transfer terms between the discourses of philosophy and of psychoanalysis - both fields have their own specific sets of rules, procedures, and objectives. However, both the category of the real in psychoanalysis and that of the inconsistent multiplicities of being in Badiou's system point to the existence of something that clearly exhausts any structure of thought. They point to the existence of something that a thought might be able to partially capture (e.g. by relying on the matheme), but which it can never fully exhaust. Lacan thinks that the matheme is the only way to (dé)montrer (show) the real; likewise, for Badiou a certain knowable segment of the real of being can be described as mathematics qua set theory. It is as if Badiou's philosophy underwent the psychoanalytic cure and was now able to accept the existence of the real.

\section{Philosophy passe again}

For Badiou, mathematical ontology is the transmissible knowledge of being, while for Lacan, the matheme constitutes the transmissible knowledge of the real, of $a b$-sense. But what does the idea of transmissibility mean? In There's No Such Thing as a Sexual Relationship: Two Lessons on Lacan, Alain Badiou remarks that the analytical act always encounters the real that is situated between sense and non-sense. ${ }^{19}$ The existence of the analytical act can be verified only a posteriori, after the act itself, when transmissible knowledge emerges. Transmissible knowledge represented by the matheme verifies that the act as such has happened. In order to prove that a psychoanalytical act took place, Lacan invented a procedure called "the pass" (passe) consisting of a set of or-

19 See: Badiou, Cassin, There's No Such Thing as a Sexual Relationship: Two Lessons on Lacan, p. 58. 
ganized interactions between the passand (the candidate), the passers (witnesses), and a deliberating jury. This procedure was to enable the psychanalyst to verify that the produced knowledge is transmissible. Although this method was often contested, Lacan remained convinced that, unlike philosophy, psychoanalysis had the ability to produce knowledge of the real (its mathematical formalization) that could be transmitted. In contrast, philosophy, by foreclosing the real, ignored mathematical formulae; philosophy did not pass. When Badiou commented on Lacan's criticism of philosophy, he highlighted that for Lacan mathematics is "a meaning-less saying that is realized as an absolute (integrally transmissible) said. And this is precisely what the philosopher fails to grasp." ${ }^{20}$ He added that, according to Lacan, "philosophy is unaware of the register of absense. It remains stuck in the opposition between sense and non-sense. Second, philosophy, being unaware of ab-sex, cannot reach a position of knowledge in the real. Third, all philosophy ever does is make sense and truth mirror images of each other, and that is its specular paralysis. The speculative is the specular.”21 Thus, Badiou's answer to Lacan's criticism was to reconnect philosophy to transmissible knowledge, i.e. with mathematics, which is able to propose at least partial knowledge of the ontological real. While Lacan denounced philosophy for being trapped on the surface of the mirror, Badiou broke the mirror and created a set-theoretical pass for philosophy. Badiou deeply appreciated the idea of Lacan that "in psychoanalysis it is a matter of raising powerlessness (the same that makes the fantasy hear reason) to logical impossibility (the same that incarnates the real)." ${ }^{22}$ While Lacan criticized philosophy for being trapped within the powerlessness (impuissance) of the imaginary, Badiou's own project elevated the powerlessness of philosophy to logical impossibility. Instead of leaving philosophy powerless to acknowledge the immanent multiplicity of what is presented, Badiou transformed this multiplicity of what is presented into inconsistent multiplicities of being and stated that it is logically impossible to describe these multiplicities otherwise than through mathematics. In this manner, he was able to symbolize the very impossibility of describing these multiplicities and to reinvigorate philosophy's connection with truths.

\footnotetext{
20 Badiou, Lacan, Anti-philosophy 3. The Seminars of Alain Badiou, p. 97.

${ }^{21}$ Ibid., pp. 89-90.

22 Lacan, ...or Worse. The Seminar of Jacques Lacan, Book XIX, p. 219.
} 
In Badiou's ontology, such logical impossibility appears in the distinction between consistent and inconsistent multiplicities. An inconsistent multiplicity cannot be counted as one, it cannot be transformed into a set. It is an ungraspable horizon of thinking. Being is composed precisely of such inconsistent multiplicities that - for they cannot be named, nor counted-as-one - appear as a void from the point of view of consistency. Badiou emphasizes that "void is the name of being - thus inconsistency - according to a situation" ${ }^{23}$ and that "[d]issemination without limits is the presentative law itself." ${ }^{24} \mathrm{~A}$ consistent multiplicity is a multiplicity that can be counted as one, that can become a set. A consistent multiplicity is a multiplicity that is thinkable. For Badiou, there is no thinking as such without a count-as-one: "all thought supposes a situation of the thinkable, which is to say a structure, a count-as-one, in which the presented multiple is consistent and numerable." ${ }^{25}$ In other words, there is no thinking as such without the effect of the One. The existence of this One, however, is not immanent, it is a result of a count. In order to deliver a concept of multiplicity; a thinker has to decide that a certain number of multiplicities constitutes a set; he or she needs to count these multiplicities as one.

In a sense, thinking needs to act in a similar manner as set theory, which lacks a very definition of a set. At the beginning of any thinking, there is an affirmative decision stitched to the void; thinking begins with the void, with the empty set and it is precisely this One as void that enables us to think without limiting thinking due to the rigidity of the One. Badiou points out that "axiomatization is required such that the multiple, left to the implicitness of its counting rule, be delivered without concept, that is, without implying the being-of-the-one." ${ }^{26}$ Language, whether formal or verbal, does not bring any new multiplicity to life; language merely retroactively separates a given multiplicity from inconsistent multiplicities and counts it as one. Or in Badiou's words, "[1]anguage cannot induce existence, solely a split within existence. ${ }^{{ }^{27}}$ For Badiou, this affirmation is supported by the axiom of separation, which claims that for any given multiple, there exists a sub-multiple of terms which possesses the property expressed by the formula j. This implies that "what is induced by a formula of the language

${ }_{23}$ Badiou, Being and Event, p. 56.

24 Ibid., p. 33.

25 Ibid., p. 34 .

26 Ibid., p. 43.

27 Ibid., p. 47. 
is not directly an existence, a presentation of multiplicity, but rather - on the condition that there is already a presentation - the 'separation', within that presentation, and supported by it, of a subset constituted from the terms (thus the multiplicities, since every multiple is a multiple of multiples) which validate the formula." ${ }^{28}$ In a move oriented against any sophistry, Badiou affirms that language merely separates a sub-multiple from an already existent multiple; language is an act of counting and naming and not of bringing to existence.

So how can philosophy account for the One and the multiple at the same time? If we consider Lacan's statement that “in psychoanalysis it is a matter of raising powerlessness (the same that makes the fantasy hear reason) to logical impossibility (the same that incarnates the real)," ${ }^{29}$ we can divide it into two steps. The first step is the one of powerlessness and of fantasy; it is the step of the imaginary, within which philosophy is trapped, according to Lacan. Philosophy is powerless, it cannot account for the inconsistency of the real, and it forecloses multiplicities by subjugating them to the semblance of the One. For this reason, psychoanalysis is superior to philosophy: it can cure philosophy by demonstrating to it that the One is a mere semblance. The second step is the one of the logical impossibility, of the real, to which a successful cure leads. A psychoanalyst is not powerless, he or she knows that it is logically impossible to describe the inconsistency of the real, and can only rely on the matheme, which can show (dé-montrer) the real.

We can argue that Badiou adds a third step to these first two: the step of the axiom, of the count-as-one. The axiom operates a scission within uncountable inconsistency; it separates a part of it and counts it as one. Badiou's axiom does not abolish inconsistency; it acknowledges that it is logically impossible to make all multiplicities consistent. There will always be an excess of inconsistency over consistency. However, axiomatic thought can progressively expand its domain by separating larger multiplicities from the sphere of inconsistency. In other words, if Lacan's second step halts at the moment when multiplicity is preferred to the One, Badiou's third step proposes a dialectic between the One and the multiple. His third step is a dialectical one, for if there were only inconsistent and ever disseminating multiplicities, the dialectic could not exist. Badiou

\footnotetext{
$28 \quad$ Ibid., p. 46.

29 Lacan, ...or Worse. The Seminar of Jacques Lacan, Book XIX, p. 219.
} 
not only breaks the mirror of the sophistry, but he also refutes the scepticism of psychoanalysis, and revives the philosophical dialectic. He brings back a third element, which is the symbolic related to the existence of universal and eternal truths. In Being and Event, Badiou describes a truth procedure as an infinite series of enquiries - each of these enquiries contains, in a finite number, positive indications $\mathrm{x}(+)$ that the multiple $\mathrm{x}$ is connected to the name of an event, as well as negative indications $y(-) .^{30}$ Thus, a truth procedure might be described as an elementary procedure of symbolization, with the only difference being that it does not relate to the Name-of-the-Father but to the Name-of-the-Event, or the name of one of the events, to be more precise. By making philosophy go through the first two steps of powerlessness and of logical impossibility, Badiou gives militant power back to philosophy. Philosophy passe again.

Divided into fragments, the three steps could like this:

\begin{tabular}{|l|l|l|l|l|}
\hline 1. & powerlessness & $\begin{array}{l}\text { phantasm of the } \\
\text { existence of the One }\end{array}$ & $\begin{array}{l}\text { faufilosofie } \\
\text { according to } \\
\text { Lacan }\end{array}$ & imaginary \\
\hline 2. & logical impossibility & $\begin{array}{l}\text { there are only } \\
\text { multiplicities of } \\
\text { multiplicities }\end{array}$ & psychonalysis \\
axiom (affirmation) $=$ & $\begin{array}{l}\text { the dialectic of } \\
\text { the count-as-one } \\
\text { and inconsistent } \\
\text { multiplicities }\end{array}$ & $\begin{array}{l}\text { Badiou's } \\
\text { philosophy }\end{array}$ & real \\
\hline
\end{tabular}

By staying trapped or bouché within the second step, Lacan seems to embrace the position of multiplicities of multiplicities, which can also be characterized as a sceptical position. Lacan's removal of the One is the reason why Alain Badiou asks, during a dialogue with Jean-Claude Milner concluding his 1994-1995 seminar, whether there is thought (pensée) in Lacan's work. This question refers to Lacan's attempt to create non-unifying thought. According to Badiou, thought needs the One, it needs the count-as-one; otherwise it would become a mere ontological inconsistency. Badiou affirms: "a thinking that is not unifying is not even a thinking, if by thinking, once again, is meant something that

3o Badiou, Being and Event, pp. 333-334. 
unifies theory and practice in an effective process." ${ }^{31}$ In a sense, thinking that is pas-tout is not thinking at all. Thus, at the end of the seminar, Alain Badiou and Jean-Claude Milner play with the assertion that "there is thinking in Lacan" and this "there is" (il $y$ a) functions in the same way as there is one (Y'd'l'Un). If there is thought in Lacan, it is a thought that must be constructed a posteriori, for there are multiple possible readings of Lacan. Lacan is a protean figure: he can be seen as a reactionary sceptic as well as a critical analyst of capitalism. In spite of all his criticism, it is the latter that Badiou tries to rediscover.

An idiosyncratic trait of Lacan which complicates this rediscovery is that he argues from the side of the real. And the contemporary real, as Badiou points out, is the real of Capital: "the real of Capital is the real of universal dispersal, circulation, and absolute atomization. Furthermore, it's a certain regime of jouissance, hence of the real." ${ }^{32}$ To speak only from the side of the inconsistency and of dissemination would be to deprive thinking of its capacity to construct the One and to effectively resist the real of Capital. Thought based only on dissemination would end up becoming complacent with the capitalist system. A truly resistant thought must also affirm; it must be grounded in an axiom stitched to the inconsistency of the real.

In addition, Lacan criticized Marx for being a philosopher. According to him, Marx instilled sense into the proletariat; he restored order by transforming the proletariat into a group while the proletariat was supposed to be a hole of the real. ${ }^{33}$ Lacan lambasted Marx for transforming the inconsistent void into a set called "the proletariat", which he counted-as-one. He saw this counting as a return of conservatism, a restoration of order. In "Responses to Students of Philosophy Concerning the Object of Psychoanalysis” from 1966, he refuted the Marxist idea that a subject could overcome his or her alienation. According to Lacan, the subject is always alienated by the desire of the Other and by its relation to the object. Alienation constitutes a fundamental existential condition of the subject and it would be naive to believe that we can overcome it otherwise than in a purely imaginary manner. Such imaginary overcoming would turn

\footnotetext{
Badiou, Lacan, Anti-philosophy 3. The Seminars of Alain Badiou, p. 196.

Ibid., p. 110.

Quoted in: Badiou, Lacan, Anti-philosophy 3. The Seminars of Alain Badiou, p. 112.
} 
into a planetary embourgeoisement. ${ }^{34}$ When confronted by students asking him about the relationship between psychoanalysis and Marxism, Lacan proposed a non-interventionist approach: on the one hand, "psychoanalysis does not have the slightest right to interpret revolutionary practice," ${ }^{35}$ but on the other hand, "revolutionary theory would do well to hold itself responsible for leaving empty the function of truth as cause, when therein lies, nevertheless, the first supposition of its own effectiveness." ${ }^{36}$ Thus, in a rather twisted paradoxical formulation, Lacan simultaneously suggests that revolutionary theory should embrace inconsistency and give up on the function of truth as cause, and he also acknowledges that without truth, revolutionary theory would be powerless. He calls for the abolishment of the notion of truth as cause (which he might have seen as a faufilosofical fantasy of the existence of the One), but he is also aware that this abolishment would put the final nail in the coffin of leftist thinking. In fact, his position seems to oscillate between a critical analysis of the capitalist real and a certain scepticism. And Badiou remarks that such a position can be interpreted in political terms only with difficulty; one can hardly extract from Lacan's thought an answer to the question "What is to be done?". He observes that maintaining the proletariat as the hole of the real would resemble in praxis only some form of "tyrannical anarchism." ${ }^{37}$ In other words, Badiou realizes that to preserve philosophy as a resistant praxis, it is necessary not to give up on philosophy's desire for truth.

\section{Subject of truth(s)}

The key point of divergence between the philosopher and the analyst concerns the notion of the subject. Badiou deeply appreciates Lacan's renewal of the category of the subject, which eluded both the structuralist discourse on the death of the subject and the phenomenological dissolution of the subject within consciousness. He generally considers Lacan's reformulation of the notion of the subject, in line with mathematical formalization, to be an important and singular intellectual investigation. He notes, for instance, that Lacan "takes part in

34 See: Jacques Lacan, "Responses to Students of Philosophy Concerning the Object of Psychoanalysis", in Television: a Challenge to Psychoanalytic Establishment, trans. D. Mollier et al., New York, W. W. Norton \& Company, 1990, p. 111.

35 Ibid.

36 Ibid.

37 Badiou, Lacan, Anti-philosophy 3. The Seminars of Alain Badiou, p. 129. 
the break with phenomenology, all the more so to the extent that he knew well the thought of Sartre and Merleau-Ponty. He inserts himself into the structuralist galaxy not only because he had recourse, much more than many others, to logico-mathematical formalisms, but also because he renounced the reflexive subject as the center of all experience." ${ }^{8}$ He praises the fact that Lacan decentred the subject and abolished the subject's presumed transparency to itself. In contrast to Foucault or Derrida, Lacan's revealing of the internal contradictions of the subject enabled him to preserve this category and place it at the centre of clinical experience.

So how does Lacan's notion of the subject compare to Badiou? Unlike in Badiou's work, where the subject is a result of the process of the incorporation of a truth, in Lacan's work, the subject often appears as a generic name of the human being. It is important to note that Lacan's subject cannot be restricted to the ego, or as Lorenzo Chiesa remarks: "the ego is not the subject tout court; on the contrary, it corresponds to the subject's identifying alienation in the imaginary other (an other that initially corresponds to the subject's specular image): in parallel, psychoanalysis does not aim at strengthening the ego but instead at realizing the subject of the unconscious through the overcoming of imaginary alienation." ${ }_{39}$ The ego is a false unity, a false semblance of the One, it is "an imaginary identification, or more exactly, an enveloping series of such identifications." ${ }^{40}$

The subject is composed of multiplicities, of the triad of the ego, superego, and id; it contains multiple strata of subsequent individuations and knots together the symbolic, the imaginary, and the real. It is always defined by its relation to the imago (in the mirror stage) and by its relation to the Other (in the Oedipus complex). Lacan describes the subject as clivé, divided. He develops the Freudian idea of the Ich-Spaltung by showing that the subject is always divided between the subject of the statement and the subject of enunciation. He also stresses the false unity of the Cartesian statement cogito ergo sum. He affirms,

38 Alain Badiou, Elisabeth Roudinesco, Jacques Lacan, Past and Present: A Dialogue, New York, Columbia University Press, 2014, p. 8.

39 Lorenzo Chiesa, Philosophy and Otherness. A Philosophical Reading of Lacan, Cambridge, MIT Press, 2007, p. 14 .

$4^{0}$ Lacan, "Responses to Students of Philosophy Concerning the Object of Psychoanalysis", p. 110. 
for instance: "I am thinking where I am not, therefore I am where I am not thinking," ${ }^{\prime 11}$ ubi cogito, ibi sum, or "I am the plaything of my thought; I think about what I am where I do not think I am thinking. ${ }^{\text {"’ }}{ }^{2}$ In this way, Lacan strives to demonstrate that the Cartesian "I" is always split between thinking and its presence, where I think, I am not, I am absent. Where I am present, I do not think. The subject is split between the enunciation (the deictic I) and the statement itself. The subject that talks not only conveys the message, but also hears itself speaking. The subject's unity is merely illusory, for there is always an excess of the unsymbolizable real. Thus, the subject is a retroactive effect. According to Lacan, "the subject of the 'I think' reveals what it is: the being of a fall. I am that which thinks: 'Therefore I am,' as I have commented on elsewhere, noting that the 'therefore,' the causal stroke, divides inaugurally the 'I am' of existence from the 'I am' of meaning." ${ }^{\prime 3}$ The subject is divided between the existence - I am and the effect of the signifier which follows it - I think. It is split into two parts by the fall of the signifier.

The scission of the subject also appears in Lacan's quote of the famous Freudian sentence: "wo es war, soll ich werden," or "where id was, ego shall be." Lacan uses this quote in order to show that the place of the subject is always determined by the unconscious, by the Other. The ego emerges where the id has already been; it follows the id. The "I" is shifted outside of itself. There is no transparency of the self because when the "I" speaks, the id speaks in my place: ça pense. I remain divided between the subject of my message and the subject of enunciation.

This split (Spaltung) makes the Lacanian subject empty, béant. For Lacan, the subject is a point containing a void; it resembles an empty set. Although Lacan suppresses the Cartesian transparency of the cogito by dividing it between the "I" of the thinking and the "I" of the enunciation, he does not repeal the idea that cogito is somehow empty. While for Descartes the subject as cogito is an empty category defined by nothing other than the very reflexive act, for Lacan the subject is an abyss, a void separating thinking and enunciation. Lacan's formalizations are rather complex; however, the subject seems to be the void that

${ }_{41}$ Lacan, Écrits, p. 430.

42 Ibid.

43 Lacan, "Responses to Students of Philosophy Concerning the Object of Psychoanalysis", p. 108. 
results from a mathematical operation. While Descartes's subject can be compared to zero, Lacan's might resemble a simple count such as $1+(-1)=0$.

Badiou had been progressively demarcating his notion of the subject from Lacan. In Theory of the Subject, from 1982, a book that was still very much indebted to Lacanian formalism, Badiou sympathizes with Lacan's denunciation of "l'idéallinguisterie." However, he also stresses that the subject cannot be defined from the point of view of the structure; it is always an exception within the structure. In other words, "any subject is a forced exception, which comes in second place." ${ }^{\prime \prime 4}$ Badiou realizes that the subject is not something given; it is an a posteriori name of a procedure. He denounces the existential and limitative function of what he calls the classical idealist subject (such as the one of Immanuel Kant), which is generally posited as something from which one departs, not where one arrives. He claims that "the classical subject is thus an operator endowed with a double function. On one hand, it assignates an irreducible being of the existent; on the other, it limits that which, from the 'remainder' of being, is accessible to knowledge. It partitions that which is immediately given and that which is mediately refused to experience." 45 The classical subject is a point of departure of the correlation between "I" and the exterior world. It creates a scission between the immediacy of what is given to the subject, of what the subject perceives, and the impossibility of knowing the a-subjective, objective reality. This subject is split between the phenomenal perception and the impossibility of knowing the thing-in-itself. In contrast, Badiou affirms that "a subject is nowhere given (to knowledge). It must be found." ${ }^{\prime 6}$ The subject is neither a place within the structure, nor a generic name of a human being. It is an exception from the law, for it necessarily exceeds the structure.

It might be for this reason that, in Theory of the Subject, he denounces Lacan's extreme algebrization of the subject and some of the notions from his 1966 rewriting of "Seminar on 'The Purloined Letter", published in Écrits. Badiou disagrees with Lacan's statement that "subjectivity has no relation to the real, but rather to a syntax that is engendered by the signifying mark there. ${ }^{947}$ He reads

\footnotetext{
44 Alain Badiou, Theory of the Subject, trans. B. Bosteels, New York, Continuum, 2009, p. 84.

45 Ibid., p. 278.

46 Ibid.

47 Lacan, Écrits, p. 38.
} 
this statement as an extremely structural conception of the subject that forecloses the real. In Badiou's perspective, the subject is a knot tying together the place (the structure) and what is out-of-the place, what exceeds the place. He links subjectivation with clinamen, a deviating atom that does not follow any law. Clinamen is an exception from the law, from the structure, and as such, it maintains a close relation to the void. Clinamen is the name of the void, an empty set. Or, as Badiou puts it: "if an atom relates to the void in a manner that is not the general rule for all atoms, it may function as [an] atomistic designation of the void itself." ${ }^{\prime 8}$ He remarks, however, that it would be more precise to think of clinamen as subjectivation, but not as the subject. Thus, the subject relates to the void and to inconsistency, but the subject as such is not a void. In fact, it is not the category of the void per se, but a question of the localization of the void in relation to the subject that is at the origin of Badiou's dissent with Lacan. Although Badiou is convinced that the subject somehow relates to the void, he refuses to see the subject as voided, empty.

In Being and Event, Badiou affirms that being is composed of inconsistent multiplicities of multiplicities and that thinking can separate certain multiples from the inconsistency and count them as one. Badiou, in line with an elementary set theoretical symbolization, distinguishes two possible kinds of relations between sets: belonging and inclusion. To belong to a situation means "to be presented by that situation, to be one of the elements it structures," ${ }^{, 99}$ in philosophical terms, this can be translated as presentation. When we say that $a$ belongs to $b$, it simply means that a is present within $\mathrm{b}$, but we cannot infer from that that $a$ would be a part of $b$ because there is no count-as-one. To be included in a situation means "to be counted by the state of the situation," ${ }^{\circ 0}$ and inclusion is equivalent to representation by the state. $a$ is included in $b$ means that $a$ is a part of $b$, it is counted-as-one. Badiou distinguishes the situation and the state-of-the-situation (l'état de la situation). He adds that every situation is structured twice: the state-of-the-situation is doubled, there is no presentation of the inconsistency, of the void, or of being-qua-being. The void qua being is universally included; it constitutes an excess of any situation.

\footnotetext{
48 Badiou, Theory of the Subject, p. 58.

49 Badiou, Being and Event, p. 102.

50 Ibid.
} 
Badiou describes the event as the reshuffling of belonging and inclusion. During the event, what previously only belonged to the situation is counted by the state-of-the-situation. For instance, during the event called "revolution", a precarious mass of workers that constituted the void of the situation can be counted-as-one and receive the name of proletariat; it becomes conscious of its destiny and of its political rights. The event is a moment in which the ontological inconsistency intrudes into the consistency and radically modifies the terms of the situation. What Badiou names an "evental site" is a founding set, a set that is "on the edge of the void," " for none of the elements of this set is included in the situation. The evental site is a founding inconsistency that cannot be divided into smaller elements, it is a hotbed of the event.

In a given situation, how can we decide whether an event happened or not? An event is the a posteriori name of a process during which a new set came into existence. It is never a part of the state; it exceeds the state. For an event to exist, a subject must intervene, it must name the event as such and follow its consequences. The subject makes the event exist by remaining faithful to it and by organizing its consequences in time. A subject's defining quality is fidelity; without fidelity, there would be no subject as such. Badiou remarks that "a fidelity is the apparatus which separates out, within the set of presented multiples, those which depend upon an event. To be faithful is to gather together and distinguish the becoming legal of a chance." ${ }^{2}$ The subject connects the event and fidelity; it is "the process itself of liaison between the event (thus the intervention) and the procedure of fidelity (thus its operator of connection)." ${ }_{53}$

For Badiou, subjectivation is supported by the existence of infinite and universal truths. A truth is "an infinite part of the situation," ${ }^{44}$ or in mathematical terms, a generic set. "A truth groups together all the terms of the situation which are positively connected to the event." 55 It appears in the world via four generic truth procedures: art, love, politics, and science. To say that a truth is infinite means simply that "its procedure contains an infinity of enquiries." ${ }^{56}$ Human

\footnotetext{
${ }^{51} \quad$ Ibid., p. 175.

$52 \quad$ Ibid., p. 232.

53 Ibid., p. 239.

54 Ibid., p. 333.

55 Ibid., p. 335.

$56 \quad$ Ibid., p. 333.
} 
being can become subject only through the incorporation of these universal and infinite truths and fidelity to an event. A subject is "any local configuration of a generic procedure from which a truth is supported." ${ }^{57}$ One is not born a subject; one can only become a subject through the embodiment of truth(s). Truths and subject are like communicating vessels - one cannot exist without the other. A truth is always transcendent to the subject; it is an "un-presented part of the situation." ${ }^{8}$ In Badiou's words: "every truth is transcendent to the subject, precisely because the latter's entire being resides in supporting the realization of truth. The subject is neither consciousness nor unconsciousness of the true." 59 In a truth procedure, the subject incorporates its excess; a finite subject embodies infinite truths. The subject is a finite occurrence of truth.

In the lecture from 1967, "On Psychoanalysis in its Relation to Reality," Lacan remarks that "the body makes the bed of the Other through the operation of the signifier," ${ }^{\circ 0}$ and that the body is always divided, voided by the signifier. The body is the place of the Other. Badiou approves this idea of the body as the place of the Other, but for him the body is transformed by a universal and infinite truth: "we can also grant Lacan that the body is the place of the Other, since for us it is only the evental becoming-Other of the site which commands the possibility of a body of truth." ${ }^{{ }_{11}}$ Yet, if the divisive action of the signifier makes the body voided for Lacan, for Badiou, the subject's body is rather filled by truths. In his works, the subject, instead of being empty, is often described as full. The body is transformed, it incorporates truths.

Badiou locates the void in being, whereas for Lacan, the void is situated in the subject. Badiou affirms: "the place at which philosophy localizes the void as the condition of thought is being, qua being. The place at which psychoanalysis localizes the void is the Subject, its subject, the Subject as the unconscious that occupies the gap between signifiers in which the metonymy of its being

\footnotetext{
Ibid., p. 391.

Ibid., p. 396.

Ibid., p. 397.

Jacques Lacan, "De la psychanalyse dans ses rapports avec la réalité”, in: Autres Écrits, Paris, Seuil, 2001, p. 357 [my translation].

61 Alain Badiou, Logics of Worlds, p. 479. [The English version translates "lit de l'Autre" as "the place of the Other" and not as "the bed of the Other", but this expression refers to Lacan.]
} 
proceeds." ${ }^{\prime 2}$ By placing the void outside of the subject, Badiou is able to avoid falling into the classic idealist notion of the subject. His subject is not empty: it is simultaneously filled by local particularities (such as gender, race, and any personal complexities that can constitute material for psychoanalysis) and by truth procedures exceeding these particularities and pointing at something infinite outside of the subject. Badiou's subject is neither empty, nor particular; the subject is singular and traversed by truth(s). Truth is not the cause of the subject, but material from which the subject is composed: "if it were necessary to identify a cause of the subject, one would have to return, not so much to truth, which is rather its stuff, nor to the infinity whose finitude it is, but rather to the event. Consequently, the void is no longer the eclipse of the subject; it is on the side of being, which is such that its errancy in the situation is convoked by the event, via an interventional nomination."63 If there were a cause of the subject, it would be the event, since it constitutes a starting point of any procedure of subjectivation.

In his confrontation with Lacan, Badiou tried to respond to two contradictions: philosophy's relation to the real and the question of the subject's internal division and of its relation to the void. Such interrogation might have been motivated by certain ethical and political implications. For by moving the subject away from its internal aporias, Badiou created the possibility of a renewed militancy. The subject follows an infinite and transcendent truth. If the capitalist procedure consists in reorienting human desire, it might be much easier to place an alternate, alienating desire in an empty, voided subject. However, if the subject is already "filled" by truth, it can better resist the temptation to give up on one's desire. The ultimate desire of the finite subject is the infinity of truth. Thus, the subject's ethical imperative is to continue and to demand the impossible. In the tragic drama of life, the subject might be the hero, whose task is to overcome the logical impossibility and follow a truth.

\section{References}

Badiou, Alain, Being and Event, trans. O. Feltham, New York, Continuum, 2008. Badiou, Alain, Conditions, trans. S. Corcoran, New York, Continuum, 2008.

62 Badiou, Conditions, pp. 202-203.

${ }_{3}$ Badiou, Being and Event, p. 433. 
Badiou, Alain, Theory of the Subject, trans. B. Bosteels, New York, Continuum, 2009.

Badiou, Alain, Logics of Worlds: Being and Event, 2, trans. A. Toscano, New York, Continuum, 2009.

Badiou, Alain, Lacan, Anti-philosophy 3. The Seminars of Alain Badiou, trans. K. Reinhard and S. Spitzer, New York, Columbia University Press, 2018.

Badiou, Alain, Roudinesco, Elisabeth, Jacques Lacan, Past and Present: A Dialogue, trans. J. E. Smith, New York, Columbia University Press, 2014.

Badiou, Alain, Cassin, Barbara, There's No Such Thing as a Sexual Relationship: Two Lessons on Lacan, trans. S. Spitzer and K. Reinhard, New York, Columbia University Press, 2017.

Chiesa, Lorenzo, Philosophy and Otherness: A Philosophical Reading of Lacan, Cambridge, MIT Press, 2007.

Lacan, Jacques, "Responses to Students of Philosophy Concerning the Object of Psychoanalysis", in Television: a Challenge to Psychoanalytic Establishment, New York, trans.

D. Hollier et al., W. W. Norton \& Company, 1990.

Lacan, Jacques, "De la psychanalyse dans ses rapports avec la réalité”, in: Autres Écrits, Paris, Seuil, 2001, pp. 351-359.

Lacan, Jacques, “LÉtourdit” in: Autres Écrits, Paris, Seuil, 2001, pp. 449-495.

Lacan, Jacques, Écrits, the First Complete Edition in English, trans. B. Fink, New York, W. W. Norton \& Company, 2006.

Lacan, Jacques, ...or Worse, The Seminar of Jacques Lacan, Book XIX, trans. A. R. Price, Cambridge, Polity, 2018.

Tho, Tzuchien, “Antiphilosophy”, in Steven Corcoran (ed.), The Badiou Dictionary, Edinburgh, The Edinburgh University Press, 2015. 